\title{
Journal of Coaching Education
}

\section{Athletes’ Perceptions of Coaches' Emotional Intelligence Competencies}

Jennifer L. VanSickle, EdD.

University of Indianapolis

Heidi Hancher-Rauch, Ph.D., CHES

University of Indianapolis

Terry G. Elliott

Morehead State University

\begin{abstract}
This study compared intercollegiate athletic coaches' self-perceptions to the perceptions of their players concerning a coach's emotional intelligence. Sixteen coaches and 223 players from two Division I softball conferences completed the Emotional Competence Inventory-2 (Boyaztis, Goleman, \& Hay/McBer, 2001). Mean analysis revealed that coaches rated themselves higher on 14 of the 18 emotional intelligence competencies and on all four emotional intelligence clusters. Coaches rated themselves highest in Social Awareness (Error! Bookmark not defined. $\bar{x}=4.27 / 5$ ) while their athletes rated them highest in SelfAwareness (Error! Bookmark not defined. $\overline{\mathrm{x}}=3.63 / 5$ ). Meanwhile, athletes gave coaches their lowest rating in Relationship Management (Error! Bookmark not defined. $\bar{x}=3.44 / 5$ ). Coaches need to be aware that the selfperceptions of their own behavior differ from the perceptions of their athletes. Since it is well known that the behavior of the coach affects the performance of the athlete, techniques to train coaches to recognize and overcome this difference could be beneficial and are provided.
\end{abstract}




\section{Journal of Coaching Education}

\section{Athletes’ Perceptions of Coaches’ Emotional Intelligence Competencies}

\section{Introduction}

The ability to lead is essential for successful athletic coaches. Over the years, coaches have espoused their theories and methods of leadership both in the athletic realm and to the business world. While researchers in business have invested significant amount of time investigating and developing leadership models, research in sport leadership has lagged behind. Sport researchers, specifically Smith, Smoll, Hunt, Chelladurai, and Selah, have developed models of coaching behavior based upon the work of business researchers. These models, which produced the Coaching Behavior Assessment System (Smith, Smoll, \& Hunt, 1977) and the Leadership Scale for Sports, (Chelladurai \& Selah, 1980) allowed researchers to determine the effect of the feedback provided by coaches on athletes' self-esteem, satisfaction, and perceived competence of the coach and assessed athletes' perceptions of coaches' leadership styles. Out of these arose data that showed significant positive relationships between athlete satisfaction, athlete motivation, perceived competence of the coach, overall athlete performance and the leadership style of the coach.

Others have taken a more direct approach in transferring business models of leadership to the athletic world. Rowold (2006) and Charbonneau, Barling, \& Kalloway (2001) borrowed the theories of transformational and transactional leadership to determine if these behaviors were exhibited in coaches and to measure their impact on coaching effectiveness. Both found support for the relationship of these leadership behaviors to coaching effectiveness. Additionally, Weinberg and McDermett (2002) interviewed sport and business leaders to ascertain their perceptions of essential factors relating to organizational success and found similarities in terms of leadership, communication, and group cohesion. Finally, Jones (2002) wrote about his personal journey from working in sport to a career in business and argued that much can be learned by the sport world from excellence in business.

Recently, researchers have focused upon the theory of emotional intelligence and its potential application in sports. Emotional intelligence has been defined as " the ability to accurately perceive, appraise, and express emotion; the ability to access and/or generate feelings when they facilitate thought; the ability to understand emotions and emotional knowledge; and the ability to regulate emotions to promote emotional and intellectual growth" (Mayer \& Salovey 1997 p.10). For years, proponents of emotional intelligence have claimed that it can enhance leadership performance (Dulewicz, Young, \& Dulewicz, 2005; Goleman, Boyatzis, \& McKee, 2002; George, 2000), team cohesion (Prati, Douglas, Ferris, Ammeter, \& Buckley, 2003), and coping with pressure (Gould, Eklund, \& Jackson, 1992), all of which are vital to a coach's success and a team's performance on the athletic field.

As a construct, emotional intelligence has been heavily debated and two main approaches have emerged: the ability based model, as proposed by Mayer \& Salovey (1997), and the mixed models of emotional intelligence,

Volume 3, Issue 1, April 2010

Page 22

A publication from the National Association for Sport and Physical Education (NASPE), an association in the American Alliance for Health, Physical Education, Recreation and Dance (AAHPERD)

1900 Association Drive • Reston, Virginia • 20191 • www.NASPEinfo.org • 703.476.3410

(C)2010 by NASPE. All Rights Reserved. 


\section{Journal of Coaching Education}

developed by Goleman (1995) and Bar-On (2005). Both models involve self-awareness or the ability to perceive one's own emotional state and self-management, or the ability to regulate one's own emotions as appropriate for the situation. However, the core differences lie in the authors' conceptualization of emotional intelligence - the other factors that make up the construct, and how emotional intelligence is measured, based upon that conceptualization.

Mayer and Salovey's 1997 model referred to as the ability based model, describes emotional intelligence as a mental ability capable of bridging the gap between cognitive and emotional states. The authors' view emotional intelligence as another form of intelligence, including the ability to reason and problem solve on the basis of one's emotions (Mayer 2001). The ability based model encompasses not only emotional self-management and self-regulation but also one's ability to assimilate and understand his/her emotions (MacCann, Matthew, Zeidner, \& Roberts, 2003). The test constructed to measure these four abilities of emotional intelligence, the MSCEIT Emotional Intelligence Test, (Mayer, Salovey, \& Caruso, 2002), is a test of performance and measures only the person's individual abilities, not allowing for a measurement of others’ perceptions.

Models proposed by Goleman (1995) and Bar-On (2005), known as mixed model approaches, are trait-based and suggest that emotional intelligence encompasses both personality characteristics and mental abilities (Zeidner, Matthews, \& Roberts, 2004). This view proposes that emotional intelligence is comprised of specific traits which enable one to recognize his/her emotions and how those emotions affect work performance. Based upon this view, Goleman (1995) has identified four clusters of emotional intelligence, adding social awareness and relationship management to self-awareness and self-management. He has formulated 18 competencies that fit into these four clusters and has placed them in the ECI- 2 (Emotional Competence Inventory 2; Boyaztis, Goleman, \& Hay/McBer, 2001), a self-assessment and others-assessment measure of emotional intelligence. While some psychologists have argued that the ability based model more accurately predicts emotional intelligence as a skill (Meyer \& Fletcher, 2007), others have found utility in both the ability based and mixed model approaches (Van Rooy, Viswesvaran, \& Pluta, 2005). In their assessment of emotional intelligence Van Rooy and Viswesvaran (2004) found adequate predictive validity for the mixed model approach and its accompanying test. Goleman's mixed model approach and the ECI -2 are unique in that they offer investigators an opportunity to gauge subordinates' impressions of a leader's emotional intelligence competencies and assess a "particular combination of existing person-specific characteristics" (MacCann, et al. 2003, p. 250).

Emotional intelligence is managing feelings effectively and appropriately, enabling people to work together toward common goals (Goleman, 1995). According to Goleman, emotional intelligence is comprised of four major clusters: self-awareness, self-management, social awareness, and relationship management. Selfawareness includes understanding and assessing one's own emotional state, while self-management is the ability to regulate one's own emotions; social awareness includes detecting the emotions of others, while relationship management involves developing and influencing others.

Within each of the four clusters are specific competencies which further identify the skills exhibited by emotionally intelligent behavior in that domain. The clusters are groupings of competencies that allow them to

Volume 3, Issue 1, April 2010

Page 23

A publication from the National Association for Sport and Physical Education (NASPE), an association in the American Alliance for Health, Physical Education, Recreation and Dance (AAHPERD)

1900 Association Drive • Reston, Virginia • 20191 • www.NASPEinfo.org • 703.476.3410

(C)2010 by NASPE. All Rights Reserved. 


\section{Journal of Coaching Education}

support one another and work together to impact performance (Cherniss \& Goleman, 2001). For example, the ability to understand others and take an active interest in their concerns (empathy) would foster greater organizational awareness and could potentially result in a greater understanding of customer/employee needs (service orientation).

ECI-2 Competencies arranged by Cluster

\begin{tabular}{|c|c|}
\hline Self-Awareness & Self-Management \\
Emotional self-awareness & Emotional self-control \\
Accurate self-assessment & Transparency \\
Self-confidence & Adaptability \\
& Achievement Orientation \\
& Initiative \\
Optimism
\end{tabular}

The competencies assessed by ECI-2 are intended to measure how a person expresses and handles emotions in every day circumstances and in work situations. They measure both the person's perceived abilities (e.g., selfawareness, empathy) and the products of those perceived abilities (e.g., teamwork and collaboration, developing others, and inspirational leadership). It is through these competencies that a person demonstrates selfawareness, self-management, social awareness, and relationship management. In terms of coaching, key aspects of emotional intelligence are fundamental for a coach (Thelwell, Lane, Weston, \& Greenlees, 2008), particularly self-management and social awareness. As the central figure in the athletic environment, the coach retains the primary responsibility for the quality and direction of each athlete's sport experience and the overall success or failure of the team (Mario, De Marco, Mancini, \& West, 1997). Coaches who exhibit positive feedback behaviors are more likely to give rise to athletes with higher levels of social cohesion (Yusof \& Vasutheran, 2007) and motivation (Martin, Rocca, Cayanus, \& Weber, 2009; Amorose \& Horn, 2000). Conversely, athletes are less motivated when coaches are verbally aggressive (Martin et al. 2009). Therefore, coaches who are aware of and can control their own negative emotional impulses can act and speak constructively to athletes even in times of turmoil and distress, producing positive outcomes for the athlete and the team. Likewise, the emotions of the coach have the potential to influence the emotions of the athlete. Athletes report feeling charged, determined, and/or energetic following their coach's pre-game speech (Vargas-Tonsing, 2009; Vargas-Tonsing \& Guan, 2007). A coach who can evoke positive pre-game feelings in his/her athletes demonstrates a command of his/her own emotional state and knowledge of the sentiments that will stir them to respond. Therefore, it is incumbent upon the coach to be able to exercise emotional regulation

Volume 3, Issue 1, April 2010

Page 24

A publication from the National Association for Sport and Physical Education (NASPE), an association in the American Alliance for Health, Physical Education, Recreation and Dance (AAHPERD)

1900 Association Drive • Reston, Virginia • 20191 • www.NASPEinfo.org • 703.476.3410

(C)2010 by NASPE. All Rights Reserved. 


\section{Journal of Coaching Education}

and control, as displays of emotion may directly or indirectly influence or enhance an athlete's or team's performance. Also, key moments in competition often require that coaches recognize and control their emotions so they can think clearly about game strategy and/or refrain from garnering penalties that might adversely affect the outcome. Olympic coaches report that the ability to stay cool under pressure positively affected their ability to effectively coach their team (Gould, Guinan, Greenleaf, \& Chung, 2002). "Yelling or arguing with athletes, losing control of tempers, or arguing with officials" are common misbehaviors often engaged in by coaches (Wang \& Goldfine, 2007, p.2). Thus, the ability to control one's emotional state and conceal select emotions from the athletes has proven to be a valuable skill for coaches (Gould et al. 2002). According to the theory, emotionally intelligent coaches would know how to utilize these skills for the benefit of their athletes.

Finally, a relationship exists between an athlete's emotional state and his/her performance quality (Hanin, 2000). Individual athletes perform best when their emotional states are within their preferred range. Coaches who know and can recognize when an athlete's emotions are outside of the preferred range can modify his/her own behaviors and emotions to assist the athlete in regaining emotional control. For example anger, which is most often viewed as a hindrance to performance, may actually enhance performance if the athlete is required to perform a physical skill similar to anger's associated tendency, such as tackling in football (Woodman, Davis, Hardy, Callow, Glasscock, \& Yuill-Proctor, 2009). Therefore, in these instances, a coach might act to induce a feeling of anger in his/her athlete. Conversely, anxiety can have a debilitating effect on performance (Martens, Vealey, \& Burton, 1990). A coach who can recognize anxiety in his/her athletes can then demonstrate behaviors to reduce athlete anxiety (Baker, Cote, Hawes, 2000). Unfortunately, according to Williams, Jerome, Kenow, and Rogers (2003), coaches are not very accurate in predicting the psychological states of their athletes, nor are they accurate in perceiving the supportiveness or unsupportiveness of their own behavior. Therefore, increasing one's emotional intelligence could produce positive outcomes for the coach, athlete, and team.

Relationship management is another important area where the presence of emotional intelligence would be important for an athletic coach. Relationship management includes the ability to manage conflict, develop and inspire others, and promote teamwork and collaboration (Goleman, 2000). On every team, conflict will arise. The role of the coach is to defuse conflicts amongst players, and at times between players and the coaching staff, in order to create the unity required to win games. Additionally, there can be great pressure on coaches to win games, particularly at the collegiate level. In these situations, coaches must be able to not only improve players' abilities but also motivate them to reach individual and team goals. However, winning and developing sport specific abilities are often only a part of the job. It is also expected that participation in sport will develop character and teach moral reasoning and social responsibility, all under the guidance and direction provided by the coach. Therefore, the coach often takes on many roles including being a role model, a parent substitute, a counselor, and/or a friend. Emotional intelligence skills, particularly relationship management, might aide a coach in fulfilling these roles. "Acknowledging the wide ranging situations in which coaches operate and the contrasting personalities with whom they work, reinforces not only the need for emotional intelligence within coaches but it also identifies the many difficulties within their role where emotional intelligence may be of use" (Thelwell et al. 2008, p.231).

Volume 3, Issue 1, April 2010

Page 25

A publication from the National Association for Sport and Physical Education (NASPE), an association in the American Alliance for Health, Physical Education, Recreation and Dance (AAHPERD)

1900 Association Drive • Reston, Virginia • 20191 • www.NASPEinfo.org • 703.476.3410

(C)2010 by NASPE. All Rights Reserved. 


\section{Journal of Coaching Education}

Why are athlete perceptions important?

According to Boardley, Kavussanu, and Ring (2008, p. 271), "the critical variable in coaching effectiveness is athletes' own perceptions of their coaches' behaviors.” In order to maximize coaching/leadership effectiveness, there should be congruence between the athletes' perceptions of the coaches' behavior and the coaches' perceptions of their own behavior. Athlete perceptions are a key component of coaching effectiveness research (Chelladurai \& Selah, 1980), and are important because it is the athlete who is experiencing the coach's behavior and may be profoundly impacted by that behavior. For example, if an athlete perceives that his/her coach does not have emotional self-control but the coach believes the opposite, then the athlete and his/her performance may be adversely affected by the coach's seemingly uncontrollable emotional outbursts, while the coach perceives that his/her players are unaffected by these demonstrations of emotion. Similarly, if a coach perceives that his/her ability to inspire is adequate while the athletes feel differently, then the adjustments that the coach may or may not make to his/her behavior may prove to be inappropriate in helping the team reach its goal. Boardley, Kavussanu, and Ring found that athletes gave a greater effort and were more dedicated to their sport when they perceived that their coaches possessed positive/effective motivational abilities. Also, coachingefficacy literature has documented the importance of athletes' perceptions of their coach's behaviors relevant to coaching effectiveness and their impact on athlete performance (Kavassanu, Boardley, Jutkiewicz, Vincent, \& Ring, 2008; Myers, Feltz, Maier, Wolfe, \& Reckase, 2006). Results reveal that coaches perceive their own behaviors as more supportive, more rewarding (Wandzilak, Ansorge, \& Potter, 1998), more motivating, better in teaching technique and formulating game strategy, and more character building (Kavussanu et al. 2008) than do their athletes.

While some (Crombie, Lombard, Noakes, 2009; Zizzi, Deaner, \& Hirschhorn 2003) have suggested that emotional intelligence may benefit athletes and athletic teams, few studies have investigated its presence in the sport arena and in coaches in particular. Given the importance of athletes' perceptions of their coaches' behavior and the potential benefit of emotional intelligence, this current investigation seeks to determine whether athletic coaches believe they possesses emotional intelligence competencies and whether athletes' perceptions match that belief.

\section{Method}

\section{Participants}

A sample of coaches and players was selected from two NCAA Division I softball conferences that included a total of 23 softball programs. Players and coaches from 16 different teams completed the surveys, with an average of $70 \%$ of the athletes from each respective team completing the questionnaire. Of the sixteen coaches, two were male and 14 were female. Five of the head coaches had been at their current institutions for 1-4 years, seven had tenure of 5-9 years, and four had been for 10 or more years. A total of 223 of the 316 players (71\%) participated in the study. The majority of players (69\%) completing these surveys had played for their current

Volume 3, Issue 1, April 2010

Page 26

A publication from the National Association for Sport and Physical Education (NASPE), an association in the American Alliance for Health, Physical Education, Recreation and Dance (AAHPERD)

1900 Association Drive • Reston, Virginia • 20191 • www.NASPEinfo.org • 703.476.3410

(C)2010 by NASPE. All Rights Reserved. 


\title{
Journal of Coaching Education
}

coach for one or two years. More than half (59\%) of the players started half or more of the games in which their team competed, while only $2 \%$ did not play at all.

\section{Instrumentation}

Emotional Intelligence was measured via the Emotional Competence Inventory 2 (ECI-2, Boyaztis, Goleman, \& Hay/McBer, 2001). Coaches completed the Self-Assessment version (Cronbach's apha .63), while the OthersAssessment version (Cronbach's alpha .78) was completed by the players in order to evaluate their coach's emotional intelligence. The ECI-2 measures the18 competencies of emotional intelligence as theorized by Goleman (1995) and organized into four clusters: self-awareness, self-management, social awareness, and relationship management. The ECI-2 was chosen because it follows Goleman's theory (Goleman, 1995), which views emotional intelligence from a competency-based perspective, providing information about emotional abilities and the products that result when one possesses these emotional abilities. These products (e.g., empathy, transparency, and inspirational leadership) were the 18 competencies measured by this instrument. The ECI-2 is also unique in offering an Others-Assessment version, which allowed for the measurement of athlete's perceptions of their coach.

Questions were scored using a 6-point Likert scale as follows: 1=Never, 2 = Rarely, $3=$ Sometimes, $4=$ Often, 5 = Consistently, 6 = Don't Know. There are a total of 72 items comprising the 18 competency scales. Some of the items were reverse scored to minimize the effect of response set bias. The questions represent the diversity of behavior expected when a person demonstrates one of the competencies (Boyatzis \& Sala, 2004).

\section{ECI - 2 Example Questions}

\author{
Self-Awareness \\ Recognizes the situations that arouse strong emotions in him/her \\ Acknowledges own strengths and weaknesses \\ Self-Management \\ Stays composed and positive, even in trying moments \\ Gets impatient or shows frustration \\ Social Awareness \\ Can see things from someone else's perspective \\ Is attentive to peoples' moods or nonverbal cues \\ Relationship Management \\ Avoids conflicts \\ Changes overall strategy, goals, or projects to fit the situation
}

Volume 3, Issue 1, April 2010

Page 27

A publication from the National Association for Sport and Physical Education (NASPE), an association in the American Alliance for Health, Physical Education, Recreation and Dance (AAHPERD)

1900 Association Drive • Reston, Virginia • 20191 • www.NASPEinfo.org • 703.476.3410

(C)2010 by NASPE. All Rights Reserved. 


\section{Journal of Coaching Education}

\section{Procedure}

After obtaining Institutional Review Board approval, 23 softball teams were recruited from two Division I conferences in the Midwestern United States. Teams were initially recruited via an e-mail sent to the head coach. Sixteen of the 23 head coaches agreed to participate in the study which occurred during the final 1/4 of the competitive softball season. Upon agreement, a response form and an informed consent letter were mailed to each coach. The response form contained demographic information and an opportunity to agree or decline to participate in the study. Attached were the ECI-2 Self- Assessment and a self-addressed stamped envelope in which to return all forms. Also enclosed in the coaches' envelopes were packets for each player on his/her team. The players' packets included a letter explaining the purpose and brief description of the study, an informed consent letter, a demographic response form which provided each player with an opportunity to agree or decline to participate, the ECI-2 Other-Assessment, and directions for completing the survey. The players' packets also included a self-addressed stamped envelope in which to return all forms.

Coaches were directed to get another person to administer the survey to their athletes. Instructions asked the survey administrator to give the questionnaires to the players and request that the players read and follow the instructions. The instructions directed players to insert the completed survey into the envelope, seal it, sign their name across the seal to ensure confidentiality, and mail it directly to the researcher using the self-addressed stamped envelope provided. Coaches were charged not to be present while athletes completed the survey. Each questionnaire was coded to track participants’ return rates. After one week and once during each successive week for one month, follow-up e-mails were sent to each coach who had agreed to participate but had not returned a survey. If a coach had players whose surveys had not been received, an e-mail also was sent to the coach requesting that he/she remind the players to fill out and return the questionnaires. If respondents answered "Don't Know" to any of the ECI-2 questions, these responses were not included in the research data.

\section{Data Analysis}

Data were coded via computer and analyzed using Microsoft Excel. First, emotional intelligence competency mean scores were calculated for the athletes on each team and the team's coach. Then, mean scores were calculated for each team and coach on the four emotional intelligence clusters. These scores were then evaluated to determine trends which revealed that all athletes scored their coaches lower on emotional intelligence competencies and emotional intelligence clusters as compared to the coaches' ratings of themselves (see figures 1 \& 2). Therefore, all athlete scores and all coaches' scores were combined, forming two groups for further analysis. Next, athletes were categorized first by role and then by number of years played for their coaches to assess whether emotional intelligence perceptions differed based upon these factors. Mean scores were computed for each athlete grouping and compared to coaches’ mean scores.

Volume 3, Issue 1, April 2010

Page 28

A publication from the National Association for Sport and Physical Education (NASPE), an association in the American Alliance for Health, Physical Education, Recreation and Dance (AAHPERD)

1900 Association Drive • Reston, Virginia • 20191 • www.NASPEinfo.org • 703.476.3410

(C)2010 by NASPE. All Rights Reserved. 


\section{Journal of Coaching Education}

\section{Results}

Results of the comparison of all coaches' self-perception and all players' perceptions of their coaches' emotional intelligence revealed a trend for coaches to rate themselves higher than their players on all four emotional intelligence clusters (see Table 1). Coaches rated themselves highest in Social Awareness (Error! Bookmark not defined. $\bar{x}=4.27$ ), while the athletes tended to rate the coaches highest in Self-Awareness (Error! Bookmark not defined. $\bar{x}=3.63$ ). Athletes gave coaches their lowest rating in Relationship Management (Error! Bookmark not defined. $\bar{x}=3.44)$.

Examination of the competencies that comprise each cluster showed a similar trend. Comparing the selfperception of the coach to the perceived level of the players is shown in Table 2. The 14 competencies reflecting the greatest difference were: Accurate Self-Assessment, Emotional Self-Awareness, Adaptability, Emotional Self-Control, Optimism, Transparency, Empathy, Organizational Awareness, Service Orientation, Change Catalyst, Conflict Management, Developing Others, Influence, and Inspirational Leadership. Coaches and players were in agreement on only four emotional intelligence competencies: self-confidence, achievement orientation, initiative, and teamwork and collaboration.

Taking a descriptive look at the effect of years played for the coach on perceptions of the coaches' emotional intelligence revealed that first-year players perceived their coaches' levels of emotional intelligence much differently than those who had played successive years for their coach. First-year players scored their coaches' higher on all four emotional intelligence clusters, with the largest difference appearing in the area of selfawareness (Figure 3). Likewise, descriptive differences were found between a player's role and their perception of the coaches' emotional intelligence (Figure 4). With respect to role, two of the greatest differences were found in the areas of self-awareness and relationship management.

\section{Discussion}

All of the head softball coaches rated themselves higher in every emotional intelligence competency, when compared to the ratings of their players. This descriptive research confirms what others have said about coaches' perceptions of themselves; that they view their behaviors differently and more positively than do their athletes (Williams, et al. 2003; Wandzilak, et al. 1998; Kavassanu, et al. 2008). The largest differences in emotional intelligence competency ratings occurred with respect to transparency, empathy, and conflict management. The discrepancies between the perceptions of coaches and players in these areas could potentially have an impact on coaching effectiveness in a variety of ways. First, the discrepancy in transparency ratings indicates that coaches believed they kept their promises to their athletes, acknowledged their own mistakes, and learned from setbacks while their players did not perceive their coaches exhibited those behaviors. If players perceive that coaches do not keep their promises, levels of trust in the player-coach relationship could deteriorate, which could have a negative impact on the coach's ability to lead. The inability to establish trust with athletes is a barrier to coaching effectiveness (Gould, et al. 2002; Becker, 2009). Similarly, expert coaches cite self-evaluation, learning from mistakes, and leading by example as key components of professional growth

Volume 3, Issue 1, April 2010

Page 29

A publication from the National Association for Sport and Physical Education (NASPE), an association in the American Alliance for Health, Physical Education, Recreation and Dance (AAHPERD)

1900 Association Drive • Reston, Virginia • 20191 • www.NASPEinfo.org • 703.476.3410

(C)2010 by NASPE. All Rights Reserved. 


\section{Journal of Coaching Education}

(Vallée \& Bloom; 2005, Becker). Coaches who are not perceived as assessing and correcting their own behavior may not only hamper their own personal growth, but also may hinder their athletes' or teams' growth.

Second, when players rated their coaches' empathy, they were asked whether the coach listened attentively, related well to people of diverse backgrounds, and was attentive to others' moods and nonverbal cues. According to Cooper and Sawaf (1997), the ability to understand other people's perspectives, or empathy, was the most pronounced difference between coaches who failed and coaches who succeeded. If a coach believes that he/she is accurately reading the moods and verbal cues of his/her players and is wrong, or if a player believes that her coach is not listening attentively and the coach disagrees, this could create conflict between the two parties resulting in poor athletic performance. Athletes perceive that great coaches listen and are nonjudgmental (Becker, 2009).

Third, a discrepancy in scores on conflict management, which includes negotiating and resolving disagreements, could create large riffs between team members and the head coach, again affecting overall team performance. According to Goleman (1998), people who are adept at conflict management spot potential conflict, bring disagreement into the open and de-escalate tense situations, orchestrating win-win situations for all parties involved. However, if a player perceives that conflict is not being handled in this manner and conflicts in a team go unresolved, the inevitable result could be dissension among team members and/or resentment toward the coach. Ultimately, in this situation, the effectiveness of the coach would suffer as the inability to effectively handle crisis situations and the ability to make fair but decisive decisions are both variables which influence coaching effectiveness (Gould et al. 2002). Expert coaches are team-centered in their approaches to conflict and are proactive in limiting any behavior that is detrimental to the team (Becker, 2009).

First-year players view their coaches' emotional intelligence much differently than those who have spent more time with coach, with the trend showing that presumably the more they gets to know the coach, the lower their perceptions are of the coaches' emotional intelligence abilities (see Figure 3). Specifically athletes who have been with the coach longer view their coaches as more defensive when receiving feedback, less aware of their own strengths and weaknesses, less decisive, less willing to anticipate, recognize, meet and develop the needs of their players, and less willing to work with others to achieve goals. Because athletes were not asked about satisfaction with the coach, current win-loss record, or previous win-loss record, it is unclear as to whether or not any of these had an impact on athlete ratings, as years played for the coach explained only a small amount of the variance in emotional intelligence perceptions.

Not surprisingly, athletes who play more have different views of their coaches than athletes who play sparingly (see Figure 4). The less an athlete plays the lower they scored their coach on three of the four emotional intelligence clusters. This could be a result of an overall dissatisfaction with the coach, as other studies have shown that ability level and role are related to athlete satisfaction (Bray, Beauchamp, Eys, Carron, 2005; Voight \& Callaghan, 2006; Summers, 1991), with higher ability levels resulting in higher satisfaction and a higher rating of a coach's competence (Allen \& Howe, 1998). Amount of playing time did not influence an athlete's

Volume 3, Issue 1, April 2010

Page 30

A publication from the National Association for Sport and Physical Education (NASPE), an association in the American Alliance for Health, Physical Education, Recreation and Dance (AAHPERD)

1900 Association Drive • Reston, Virginia • 20191 • www.NASPEinfo.org • 703.476.3410

(C)2010 by NASPE. All Rights Reserved. 


\section{Journal of Coaching Education}

perception of the coaches' self-management, which includes emotional self-control, trustworthiness, conscientiousness, adaptability, drive to improve, and readiness to act.

\section{Applied implications}

The essence of emotional intelligence is awareness of one's emotions and an ability to manage them in a variety of circumstances (Goleman, 1998). Emotions are an integral part of athletics and training coaches in emotional self-awareness and self-management has the potential to improve coaching effectiveness and assist coaches in "creating a positive coaching style while maximizing fun and enjoyment," one portion of the "Teaching and Communication” area outlined in the National Standards for Sport Coaches (NASPE, 2006). Before a coach can be in command of his/her emotions, he/she must be attuned to the feelings and moods that drive his/her words and actions.

A simple method for developing emotional self-awareness is through “checking in” routines. For example, before completing a routine task (i.e., stepping on to the field or out of the office, or when placing the whistle around the neck) ask "How am I feeling right now?” Checking in provides valuable information about one's emotional state, allowing for adjustments to be made if the feelings are negative. Completing this exercise on a routine basis will cultivate self-awareness so that it eventually becomes automatic. Another simple method for developing self-awareness is by completing an emotional inventory. Setting aside a time to reflect upon and answer the following questions allows one to asses his/her emotions and reactions in order to increase selfawareness:

Do my emotions affect how I treat people? If so, when? How?

How do I react when I am stressed? Tired? Feel under attack?

How is that reaction different from when I am relaxed? Comfortable? At ease?

Likewise, social awareness, particularly empathy, can be assessed by asking the following questions about interactions with athletes, especially if the interaction resulted in conflict:

Do I allow my athletes to express their feelings?

Did I consider my athletes’ perspective?

Can I describe the look on my athletes face during our talk?

A negative response to any/all of these questions indicates a deficiency in social awareness.

Common self-management techniques include deep breathing and/or using a release. A release is a symbolic gesture designed to mimic the expulsion of negative emotions. In a situation where a coach realizes he/she is angry, simply clinching and unclenching the fist allows the coach to release the anger that has welled up inside. Taking the time to think before speaking is also an effective self-management technique.

Volume 3, Issue 1, April 2010

Page 31

A publication from the National Association for Sport and Physical Education (NASPE), an association in the American Alliance for Health, Physical Education, Recreation and Dance (AAHPERD)

1900 Association Drive • Reston, Virginia • 20191 • www.NASPEinfo.org • 703.476.3410

(C)2010 by NASPE. All Rights Reserved. 


\section{Journal of Coaching Education}

Assistant coaches, close friends, and/or former players can also be employed to aid a coach in developing emotional intelligence. Asking others to assess emotional responses can increase self-awareness, selfmanagement and social awareness skills. The following questions can be posed:

Do you think I'm overly sensitive to criticism?

Do I react defensively when something goes wrong?

Do I tend to take things personally that are not meant that way?

In what situations do you believe I overreact?

Also, a post-game analysis can provide valuable information about emotions and their effects on others. Reviewing and discussing how players' responded to situations that elicited either positive or negative emotions from the coach can be beneficial.

Finally, completing emotional intelligence self-assessments or having one's athletes complete the Coaching Behavior Questionnaire (Kenow \& Williams, 1992) and analyzing the results of the questions that pertain to emotional composure can provide a coach with insight into the athletes' perceptions of specific coaching behaviors that may have an impact on his/her effectiveness as a coach.

\section{Limitations}

The generalizability of the results of this study may be limited by a variety of factors. First, the population of this study included only softball coaches. While the personalities of coaches obviously vary on an individual basis, the accepted emotional displays of both athletes and coaches fluctuate from sport to sport. Therefore, the results of studying coaches from other sports may be very different from the ones reported here. Second, the researcher relied upon others to administer the questionnaire. As a result, the environment under which the athlete completed it is unknown. While being instructed not to do so, the potential exists that the coach administered the survey or remained in the room while the athlete was completing the survey potentially influencing the athletes' responses. Also, this study involved only coaches of female athletes. Males and females have been known to react differently to coaches and their emotions (Kulikov \& Gilbert, 2004).

Additionally, this study focused only on college teams at Division I schools. It would be worthwhile to study coaches at a variety of levels including college and high school, as the pressures of coaching and the importance of win/loss records are higher at Division I institutions. Furthermore, surveys were administered during the final $1 / 4$ of the season and win-loss record or satisfaction with playing time could influence both the athletes' attitude toward the coach and perception of the coaches' emotional intelligence. Finally, other data collection methods could yield interesting results, including observations of coaches and interviews with coaches to determine their view of emotional intelligence and its potential impact in athletics.

Volume 3, Issue 1, April 2010

Page 32

A publication from the National Association for Sport and Physical Education (NASPE), an association in the American Alliance for Health, Physical Education, Recreation and Dance (AAHPERD)

1900 Association Drive • Reston, Virginia • 20191 • www.NASPEinfo.org • 703.476.3410

(C)2010 by NASPE. All Rights Reserved. 


\section{Journal of Coaching Education}

\section{Conclusion}

Coaching an athletic team is a unique experience. This study sheds light onto the fact that differences exist between how coaches view their own emotional intelligence and how their players view them. To decrease this gap and potentially improve effectiveness, coaches should realize that their own words and actions are not always interpreted by players in a manner that they were intended. Coaches could take steps to discover how they are viewed by players and work to change those perceptions which are potentially detrimental to team chemistry. Further research is warranted to determine whether these differences in views impact the effectiveness of coaches or the success of their teams.

\section{About the Authors}

Jennifer L. VanSickle, EdD.

Jennifer is currently Associate Professor of Sport Management and Coordinator of the Sport Management program at the University of Indianapolis. Before moving to Indianapolis, she earned a Doctorate degree from the University of Kentucky and was the head softball coach at Morehead State University for ten seasons, where she was named conference coach of the year in 1999. Jennifer also spent 6 seasons coaching basketball and softball at the high school level.

Heidi Hancher-Rauch, Ph.D., CHES

After earning a master's degree, Heidi worked in the field of health promotion for a number of years before returning to school to pursue a Ph.D. in Health Education and Promotion at Purdue University. She is currently an Assistant Professor of Health Education in the Kinesiology Department at the University of Indianapolis where she teaches courses related to community and school health. She currently serves on the Board of Directors of the Social Health Association of Indiana, Inc. and the Indiana Association for Health, Physical Education, Recreation and Dance. She is a Certified Health Education Specialist.

\section{Terry G. Elliott}

Terry is an associate professor of accounting at Morehead State University. He received his Masters of Science degree from Marshall University and his Masters of Business Administration from Morehead State University. Terry is a licensed Certified Public Accountant and assists the local Small Business Administration office. 


\section{Journal of Coaching Education}

\section{References}

Allen, J.B. \& Howe, B.L. (1998). Player ability, coach feedback, and female adolescent athletes' perceived competence and satisfaction. Journal of Sport \& Exercise Psychology, 20 (3), 280-299.

Amorose, A.J. \& Horn, T.S. (2000). Intrinsic motivation relationships with collegiate athletes’ gender, scholarship status, and perceptions of their coaches behaviors. Journal of Sport \& Exercise Psychology, 22, 63-84.

Baker, J., Cote, J., \& Hawes, R. (2000). The relationship between coaching behaviors and sport anxiety in athletes. Journal of Science \& Medicine in Sport, 3 (2), 110-119.

Bar-On, R. (2005). The Bar-On model of emotional-social intelligence. Retrieved August 1, 2005 from http://www.eiconsortium.org.

Becker, A.J. (2009). It's not what they do it's how they do it: Athlete experiences of great coaching. International Journal of Sport Science and Coaching, 4 (1), 93-119.

Boardley, I., Kavassanu, M., \& Ring, C. (2008). Athletes’ perceptions of coaching effectiveness and athleterelated outcomes in rugby union: An investigation on the coaching efficacy model. The Sport Psychologist, 22, 269-287.

Boyatzis, R. E., Goleman, D., \& Hay/McBer (2001). The Emotional Competence Inventory, Boston: Hay Group.

Boyatzis, R.E. \& Sala, F. (2004). Assessing emotional intelligence competencies. In Glenn Geher (ed.), Measuring emotional intelligence: Common ground and controversy. Hauppauge, NY: Nova Science Publishers.

Bray, S.R., Beauchamp, M.R., Eys, M.A., \& Carron, A.V. (2005). Does the need for role clarity moderate the relationship between role ambiguity and athlete satisfaction? Journal of Applied Sport Psychology, 17 (4), 306-319.

Charbonneau, D., Barling, J., \& Kalloway, E.K. (2001). Transformational leadership and sports performance: The mediating role of intrinsic motivation. Journal of Applied Social Psychology, 31 (7), 1521-1534.

Chelladurai, P. \& Selah, S.D. (1980) Dimensions of leader behavior in sports: Development of a leadership scale. Journal of Sports Psychology, 2, 34-45.

Cherniss, C. \& Goleman, D. (2001). The emotionally intelligent workplace. San Francisco: Jossey-Bass. 


\section{Journal of Coaching Education}

Cooper, R.K. \& Sawaf, A. (1997). Executive EQ: Emotional intelligence in leadership and organizations. New York: Perigee.

Crombie, D., Lombard, C., \& Noakes, T. (2009). Emotional intelligence scores predict team sports performance in a national cricket competition. International Journal of Sports Science \& Coaching, 4 (2), 209-224.

Dulewicz, C., Young, M., \& Dulewicz, C., (2005). The relevance of emotional intelligence for leadership performance. Journal of General Management, 30 (3), 71-86.

George, J.M. (2000). Emotions and leadership: The role of emotional intelligence. Human Relations, 53, 10271055.

Goleman, D. (1995). Emotional intelligence: Why it can matter more than IQ. New York: Bantam Books.

Goleman, D. (1998). Working with emotional intelligence, New York: Bantam Books.

Goleman, D. (2000). Intelligent leadership. Executive Excellence, 17 (4), 17.

Goleman, D., Boyatzis, R., \& McKee, A. (2002). Primal leadership: Realizing the power of emotional intelligence. Boston: Harvard Business School Press.

Gould, D., Eklund, R.C., \& Jackson, S.A. (1992). 1988 US Olympic wrestling excellence: Mental preparation, precompetitive cognition and affect. The Sport Psychologist, 6, 358-382.

Gould, D., Guinan, D., Greenleaf, C., \& Chung, Y. (2002). A survey of U.S. Olympic coaches: Variables perceived to have influenced athlete performances and coach effectiveness. The Sport Psychologist, 16, 229-250.

Hanin, Y.L. (2000). Emotions in sport. Champaign: Human Kinetics.

Jones, G. (2002). Performance excellence: A personal perspective on the link between sport and business. Journal of Applied Sport Psychology, 14 (4), 268-281.

Kavassanu, M., Boardley, I., Jutkiewicz, N., Vincent, S. \& Ring, C. (2008). Coaching efficacy and coaching effectiveness: Examining the predictors and comparing coaches' and athletes' reports. The Sport Psychologist, 22, 383-404.

Kenow, L. \& Willaims, J.M. (1992). Relationship between anxiety, self-confidence, and the evaluation of coaching behaviors. The Sport Psychologist, 6. 344-357.

Volume 3, Issue 1, April 2010

Page 35

A publication from the National Association for Sport and Physical Education (NASPE), an association in the American Alliance for Health, Physical Education, Recreation and Dance (AAHPERD)

1900 Association Drive • Reston, Virginia • 20191 • www.NASPEinfo.org • 703.476.3410

(C)2010 by NASPE. All Rights Reserved. 


\section{Journal of Coaching Education}

Kulikov, N. A. \& Gilbert, W. (2004). Influence of athlete gender on the coaching process of successful coaches of combined gender sports. Pelinks $4 u, 6$ (1). Retrieved 1- 29-04 from http://www.pelinks4u.org/sections/coaching/coaching.htm

MacCann, C., Matthews, G., Zeidner, M., \& Roberts, R. (2003). Emotional Intelligence: A review of self-report and performance based testing. International Journal of Organizational Analysis, 11(3), 247-274

Mario, G., De Marco P., Mancini, V. H., \& West, D.A. (1997). Reflections on change: A qualitative and quantitative analysis of a baseball coach's behavior. Journal of Sport Behavior, 20 (2), 135-163.

Martens, R., Vealey, R.S., \& Burton, D. (1990).Competitive anxiety in sport. Champaign: Human Kinetics

Martin, M.M., Rocca, K.A., Cayanus, J.L., \& Weber, K. (2009). Relationship between coaches’ use of behavior alteration techniques and verbal aggression on athletes' motivation and affect. Journal of Sport Behavior, 32 (2), 227-241.

Mayer, J.D. (2001). A field guide to emotional intelligence. In J. Ciarrochi, J.P. Forgas, \& J.D. Mayer, (Eds.), Emotional intelligence in everyday life. (p.3-24), Philadelphia: Psychology Press.

Mayer, J.D. \& Salovey, P. (1997). What is emotional intelligence? IN P. Salovey \& D.J. Sluyter (Eds.) Emotional development and emotional intelligence: Educational implications (pp. 3-31). New York: Basic Books.

Mayer, J.D., Salovey, P., \& Caruso, D. (2002). Mayer-Salovey-Caruso Emotional Intelligence Test, Toronto, Canada: Multi Health Systems, Inc.

Meyer, B.B., \& Fletcher, T.B. (2007). Emotional intelligence: A theoretical overview and implications for research and professional practice. Journal of Applied Sport Psychology, 19, 1-15.

Myers, N., Feltz, D., Maier, K., Wolfe, E., \& Reckase, M. (2006). Athletes' evaluations of their head coaches competency. Research Quarterly for Exercise \& Sport, 77, 111-121.

National Association for Sport \& Physical Education (2006). Quality coaches, quality sports: National standards for sport coaches $\left(2^{\text {nd }}\right.$ ed.). Reston, VA: Author.

Prati, L.M., Douglas, C., Ferris, G.R., Ammeter, A.P., \& Buckley M.R. (2003). Emotional intelligence, leadership effectiveness, and team outcomes. The International Journal of Organizational Analysis, 11 (1), 21-40.

Rowold, J. (2006). Transformational and transactional leadership in martial arts. Journal of Applied Sport Psychology, 18 (4), 312-326.

Volume 3, Issue 1, April 2010

Page 36

A publication from the National Association for Sport and Physical Education (NASPE), an association in the American Alliance for Health, Physical Education, Recreation and Dance (AAHPERD)

1900 Association Drive • Reston, Virginia • 20191 • www.NASPEinfo.org • 703.476.3410

(C)2010 by NASPE. All Rights Reserved. 


\section{Journal of Coaching Education}

Smith, R.E., Smoll, F.L., \& Hunt, E. (1977). A system for the behavioral assessment of athletic coaches. Research Quarterly, 48, 401-407.

Summers, R. J. (1991). The association between athletes' perceptions of their abilities on the influence of the coach. Journal of Sport Behavior, 14 (1), 30-41.

Thelwell, R., Lane, A., Weston, N., \& Greenlees, I. (2008). Examining Relationships between emotional intelligence and coaching efficacy. International Journal of Sport \& Exercise Psychology, 6, 224-235.

Vallée, C. N. \& Bloom, G.A. (2005). Building a successful university program: Key and common elements of expert coaches. Journal of Applied Sport Psychology, 17 (3), 179-197.

Van Rooy, D. L. \& Viswesvaran, C. (2004). Emotional intelligence: A meta-analytic investigation of predictive validity and nomological net. Journal of Vocational Behavior, 65, 71-95.

Van Rooy, D.L., Viswesvaran, C. \& Pluta, P. (2005). An evaluation of construct validity: What is this thing called emotional intelligence? Human Performance, 18 (4), 445-462.

Vargas-Tonsing, T.M. (2009). An exploratory examination of the effects of coaches' pre-game speeches on athletes’ perceptions of self-efficacy and emotion. Journal of Sport Behavior, 32 (1), 92-112.

Vargas-Tonsing, T.M. \& Guan, J. (2007). Athletes’ preferences for informational and emotional pre-game speech content. International Journals of Sports Science \& Coaching, 2 (2), 171-181.

Voight, M. \& Callaghan, J. (2006). A structural model of the determinants and reactions to athlete dissatisfaction. International Journal of Sports Science \& Coaching, 1 (1), 37-51.

Wandzilak,T., Ansorge, C.J., \& Potter, G. (1998). Comparison between selected practice and game behaviors of youth sport soccer coaches. Journal of Sport Behavior, 40 (2), 78-88.

Wang,J. \& Goldfine, B. (2007). Coaches’ winning psychological strategies for champions. Asian Journal of Exercise \& Sport Science, 4 (1), 1-6.

Weinberg, R. \& McDermott, M. (2002). A comparative analysis of sport and business organizations: Factors perceived critical for organizational success. Journal of Applied Sport Psychology, 14 (4). 282-298.

Williams, J. M., Jerome, G. J., Kenow, L. J., \& Rogers, T. (2003). Factor structure of the coaching behavior questionnaire and its relationship to athlete variables. The Sport Psychologist. 17, 16-34.

Volume 3, Issue 1, April 2010

Page 37

A publication from the National Association for Sport and Physical Education (NASPE), an association in the American Alliance for Health, Physical Education, Recreation and Dance (AAHPERD)

1900 Association Drive • Reston, Virginia • 20191 • www.NASPEinfo.org • 703.476.3410

(C)2010 by NASPE. All Rights Reserved. 


\section{Journal of Coaching Education}

Woodman, T., Davis, P.A., Hardy, L., Callow, N., Glasscock, I., \& Yuill-Proctor, J. (2009). Emotions and sport performance: An exploration of happiness, hope, and anger. Journal of Sport \& Exercise Psychology, 31, 169-188.

Yusof, A. \& Vasutheran, M. (2007). Group cohesion of Malaysian national junior athletes. Journal of the International Council for Health, Physical Education, Recreation, Sport, \& Dance, 43 (1), 12-16.

Zeidner, M., Matthews, G., \& Roberts, R. (2004). Emotional intelligence in the workplace: A critical review. Applied Psychology An International Review, 53 (3), 371-399.

Zizzi, S.J., Deaner, H.R., \& Hirschhorn, D.K. (2003).The relationship between emotional intelligence and performance among college baseball players. Journal of Applied Sport Psychology, 15, 262-269.

\section{Figures and Tables}

Figure 1. Teams 1-8 player versus coach rating of coaches' emotional intelligence

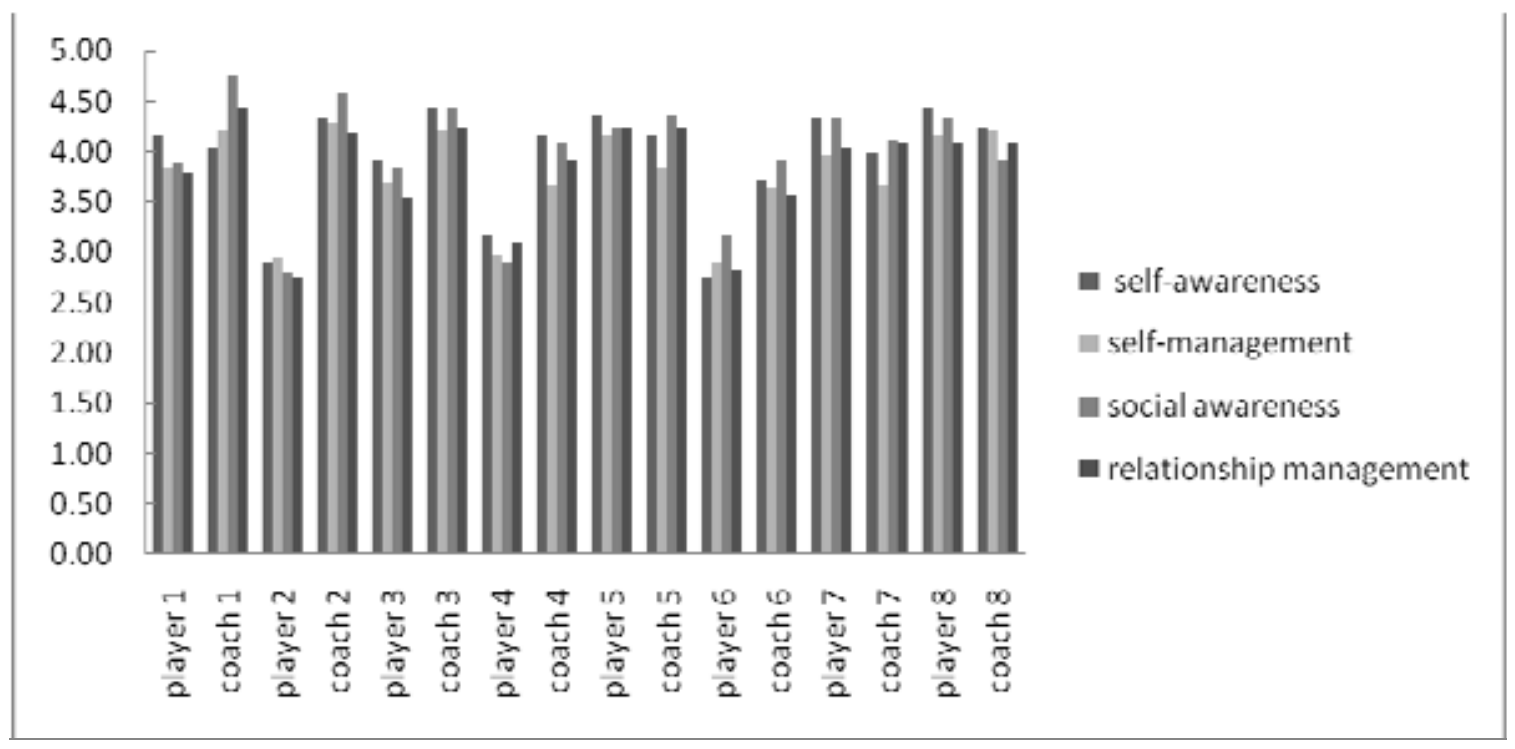

Volume 3, Issue 1, April 2010

Page 38

A publication from the National Association for Sport and Physical Education (NASPE), an association in the American Alliance for Health, Physical Education, Recreation and Dance (AAHPERD)

1900 Association Drive • Reston, Virginia • 20191 • www.NASPEinfo.org • 703.476.3410

(C)2010 by NASPE. All Rights Reserved. 


\section{Journal of Coaching Education}

Figure 2. Teams 9-16 player versus coach rating of coaches' emotional intelligence

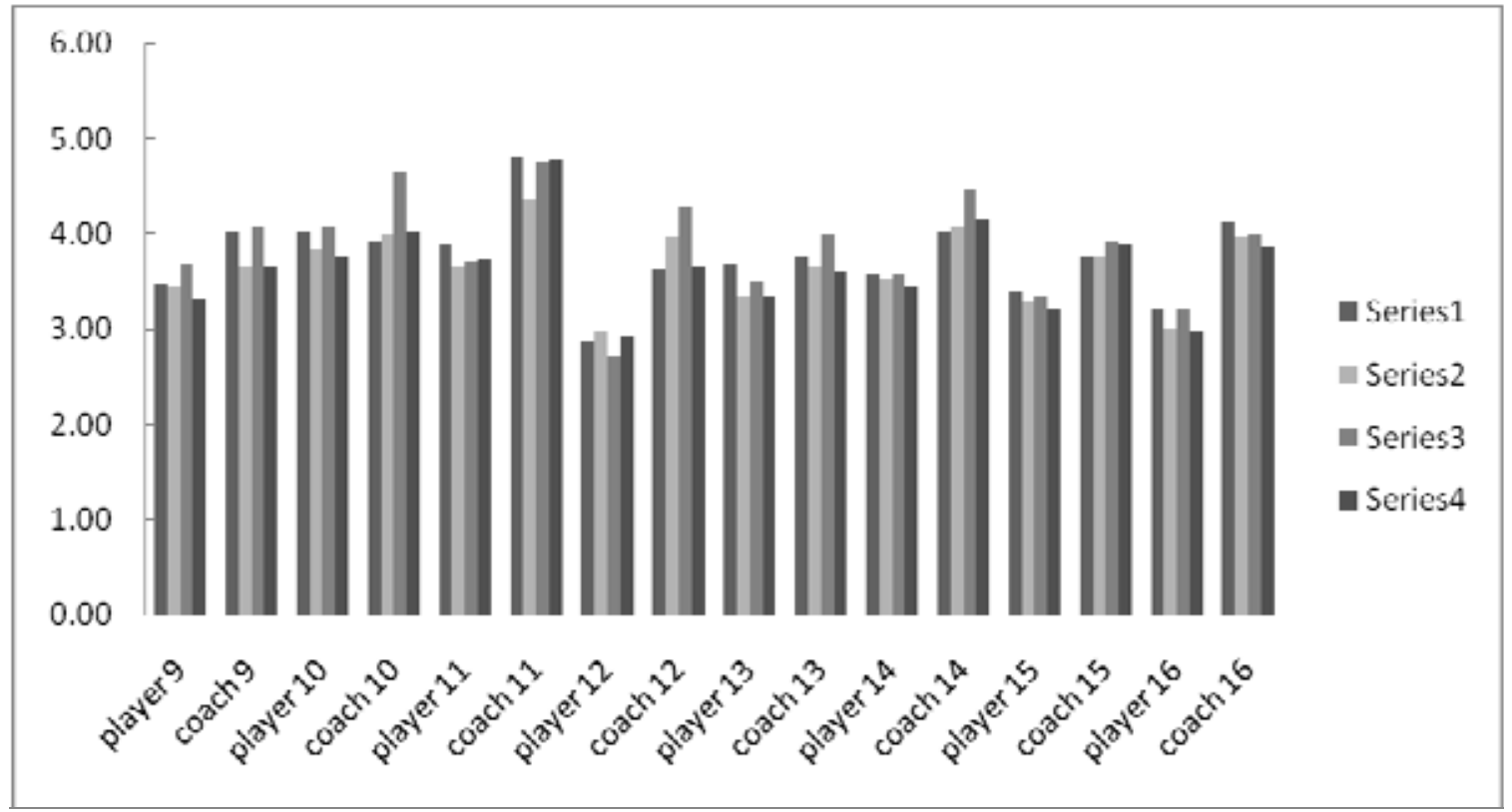

Table 1

Group Differences for EI Clusters between all Head Coaches and all Players

\begin{tabular}{|l|c|c|c|}
\hline \multicolumn{1}{|c|}{ ECI-2 Cluster } & $\begin{array}{c}M \\
\text { coaches }\end{array}$ & $\begin{array}{c}M \\
\text { players }\end{array}$ & SD \\
\hline Self-Awareness & 4.07 & 3.63 & .5852 \\
\hline Self-Management & 3.95 & 3.48 & .4561 \\
\hline Social Awareness & 4.27 & 3.58 & .5062 \\
\hline $\begin{array}{l}\text { Relationship } \\
\text { Management }\end{array}$ & 4.02 & 3.44 & .4463 \\
\hline
\end{tabular}

Volume 3, Issue 1, April 2010

Page 39

A publication from the National Association for Sport and Physical Education (NASPE), an association in the American Alliance for Health, Physical Education, Recreation and Dance (AAHPERD)

1900 Association Drive • Reston, Virginia • 20191 • www.NASPEinfo.org • 703.476.3410

(C)2010 by NASPE. All Rights Reserved. 


\section{Journal of Coaching Education}

Table 2

Group Differences for EI Competencies between all Head Coaches and all Players

\begin{tabular}{|c|c|c|c|c|}
\hline ECI-2 Competency & $M$ coaches & $\begin{array}{c}M \\
\text { Players }\end{array}$ & Difference & SD \\
\hline Accurate Self-Assessment & 3.98 & 3.39 & .58 & .7823 \\
\hline Emotional Self-Awareness & 4.04 & 3.53 & .51 & .6784 \\
\hline Self-Confidence & 4.20 & 3.96 & .25 & .5433 \\
\hline Achievement Orientation & 4.25 & 4.00 & .25 & .6527 \\
\hline Adaptability & 3.95 & 3.42 & .54 & .5119 \\
\hline Emotional Self-Control & 3.55 & 3.04 & .50 & .6452 \\
\hline Initiative & 3.42 & 3.21 & .20 & .4993 \\
\hline Optimism & 4.39 & 3.99 & .40 & .5755 \\
\hline Transparency & 4.13 & 3.19 & .93 & .5790 \\
\hline Empathy & 4.31 & 3.59 & .72 & .5107 \\
\hline Organizational Awareness & 4.14 & 3.38 & .76 & .7080 \\
\hline Service Orientation & 4.36 & 3.77 & .59 & .5984 \\
\hline Change Catalyst & 3.78 & 3.21 & .57 & .6274 \\
\hline Conflict Management & 3.64 & 3.12 & .51 & .4612 \\
\hline Developing Others & 4.11 & 3.69 & .42 & .5551 \\
\hline Influence & 3.98 & 3.60 & .38 & .6780 \\
\hline Inspirational Leadership & 3.92 & 3.32 & .61 & .6715 \\
\hline Teamwork and Collaboration & 3.96 & 3.67 & .29 & .6304 \\
\hline
\end{tabular}

Volume 3, Issue 1, April 2010

Page 40

A publication from the National Association for Sport and Physical Education (NASPE), an association in the American Alliance for Health, Physical Education, Recreation and Dance (AAHPERD)

1900 Association Drive • Reston, Virginia • 20191 • www.NASPEinfo.org • 703.476.3410

(C)2010 by NASPE. All Rights Reserved. 


\section{Journal of Coaching Education}

Figure 3. Athletes ratings of coaches' emotional intelligence by years played

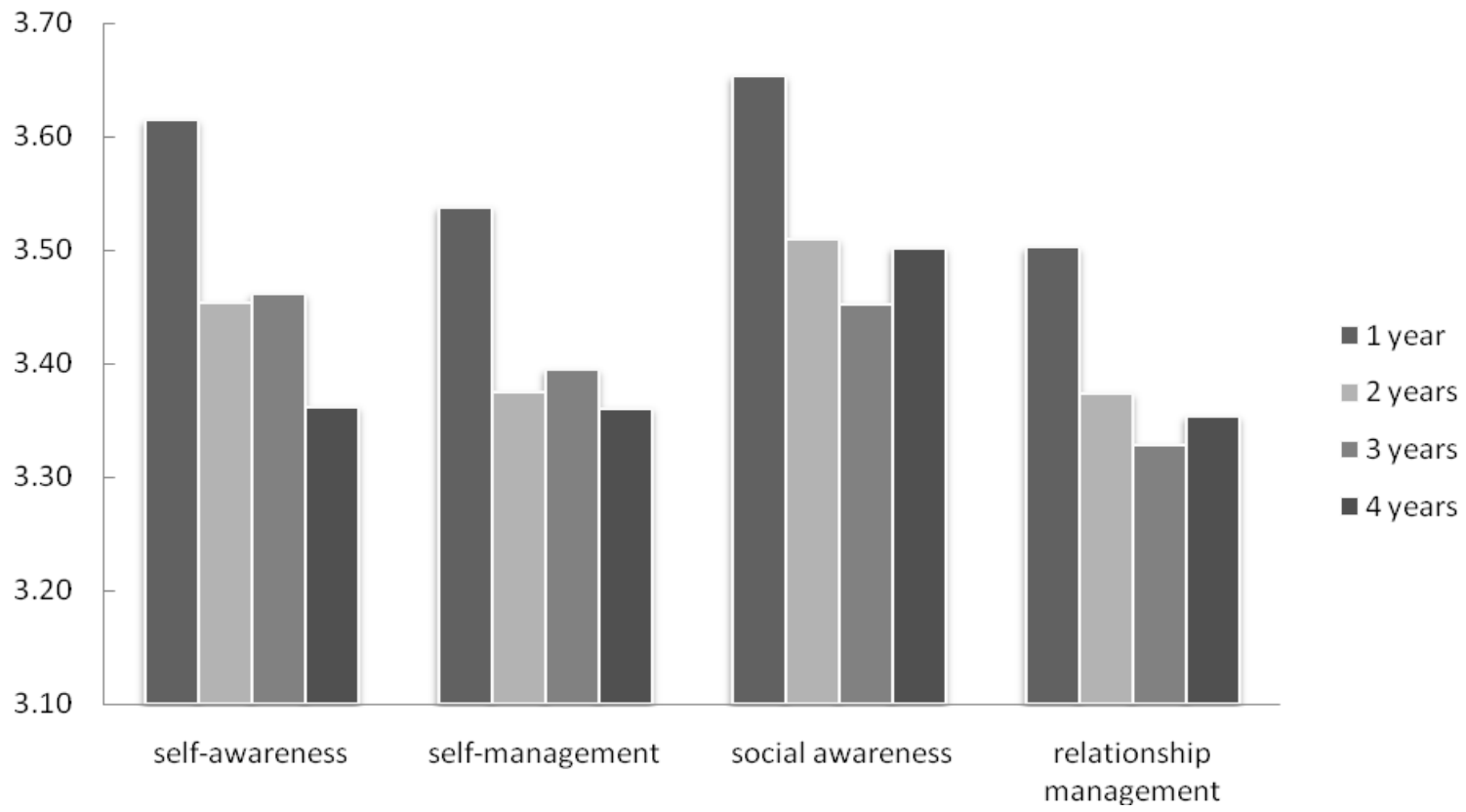

Figure 4. Athletes ratings of coaches' emotional intelligence by role

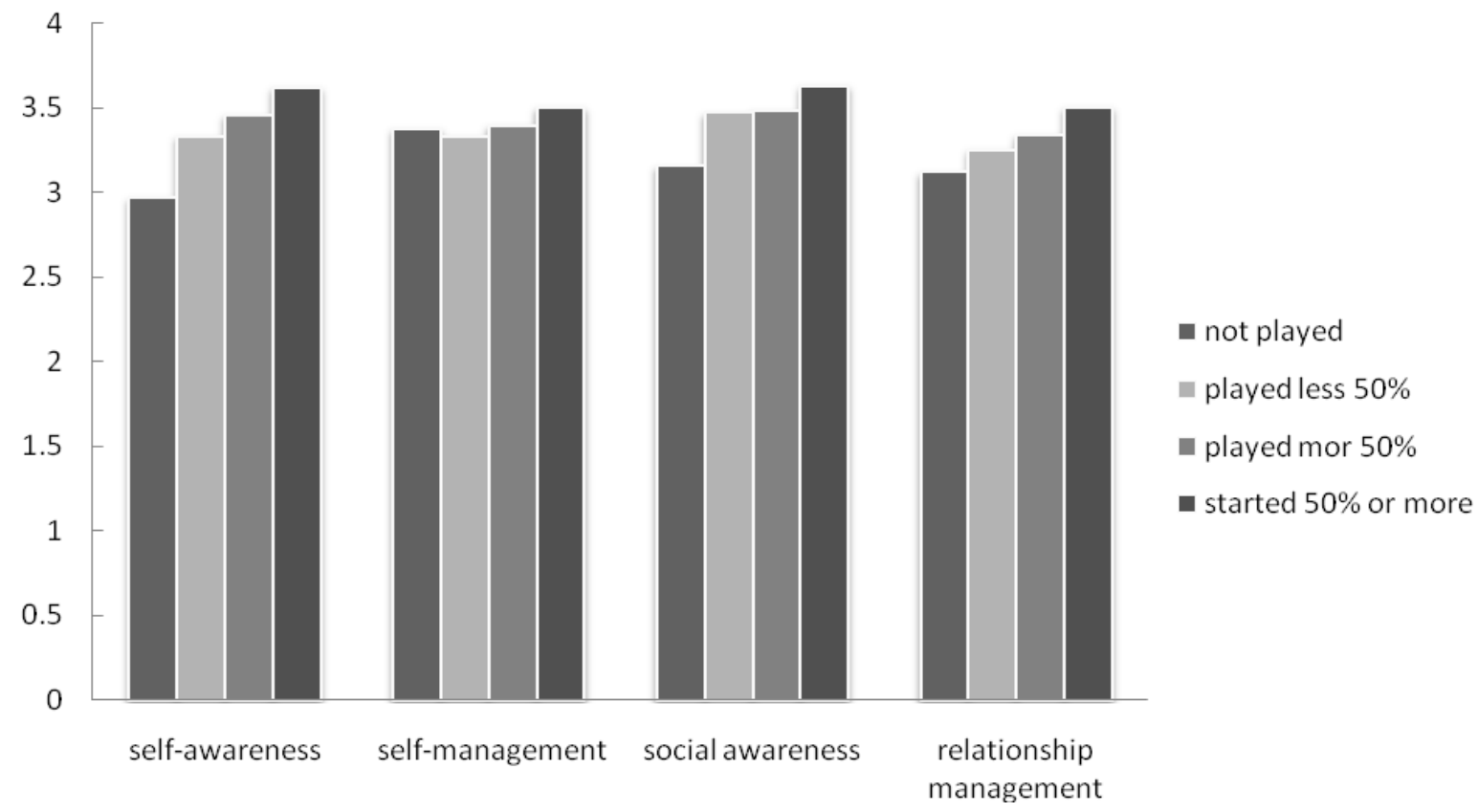

Volume 3, Issue 1, April 2010

Page 41

A publication from the National Association for Sport and Physical Education (NASPE), an association in the American Alliance for Health, Physical Education, Recreation and Dance (AAHPERD)

1900 Association Drive • Reston, Virginia • 20191 • www.NASPEinfo.org • 703.476.3410

(C)2010 by NASPE. All Rights Reserved. 